\title{
Lumen
}

Selected Proceedings from the Canadian Society for Eighteenth-Century Studies

\section{The Country and the City and the Colony in The Woman of Colour}

\section{Julie Murray}

Volume 33, 2014

URI : https://id.erudit.org/iderudit/1026566ar

DOI : https://doi.org/10.7202/1026566ar

Aller au sommaire du numéro

Éditeur(s)

Canadian Society for Eighteenth-Century Studies / Société canadienne d'étude du dix-huitième siècle

ISSN

1209-3696 (imprimé)

1927-8284 (numérique)

Découvrir la revue

Citer cet article

Murray, J. (2014). The Country and the City and the Colony in The Woman of Colour. Lumen, 33, 87-99. https://doi.org/10.7202/1026566ar d'utilisation que vous pouvez consulter en ligne.

https://apropos.erudit.org/fr/usagers/politique-dutilisation/ 


\title{
The Country and the City and the Colony in The Woman of Colour
}

\author{
Julie Murray \\ Carleton University
}

Early in the anonymously written 1808 epistolary novel The Woman of Colour, the heroine, recently arrived in England, confides in a letter to a friend that she is "disappointed in England." Having expected to encounter "sensible, liberal, well informed and rational people," she has instead met only "folly and dissimulation." Such a sentiment in a novel from this period might otherwise be unremarkable were it not for the fact that Olivia Fairfield is both an heiress and the offspring of a black mother and white father: her mother was a slave and her father was a wealthy plantation owner in Jamaica. Upon her beloved father's death and as stipulated in his will, Olivia has come to England to marry her cousin, the virtuous and liberal-minded Augustus Merton. While Olivia has no difficulty imagining a future with her cousin, Augustus proves to have a complex past that involves an obstacle to their happy union: he was married years ago to a penniless orphan, Angelina Forrester, and though he truly admires Olivia, he is unable to love her because of this prior commitment. ${ }^{2}$ The bulk of the narra-

1. The Woman of Colour, A Tale (Anon), ed. Lyndon J. Dominique (Peterborough: Broadview Press, 2008), 88. The novel was originally published by Black, Parry, and Kingsbury in London in 1808 . As for speculation about who actually wrote the novel, see Lyndon Dominique's Introduction to the Broadview edition, especially 31-32.

2. The alibi the novel offers for Augustus' inability to love Olivia is thus a convenient one: he is simply unavailable, as opposed to being constitutionally unable to love a "woman of colour," which is in fact the case with Olivia's father, who seduces her mother, his slave, but refuses to marry her. In one of the only letters in the narrative not written by Olivia, Augustus confesses to a friend what he felt when he first met Olivia: "the moment when my eyes were first cast on the person of my cousin, I

LUMEN XXXIII, 2014 • 87-99 
tive, which consists largely of letters written by Olivia to her friend Mrs. Milbanke, turns on Olivia trying to read her increasingly inscrutable husband, and acclimatizing to life in England, a world she finds alien, inhospitable, and wanting in virtue, among other things.

Olivia's disappointment with city life in particular has her hoping that Augustus will similarly "prefer [her] plan of a country life and retirement.” Pondering such questions, Olivia muses in her letter: "shall I ever more enjoy that placid happiness, that calm tranquillity, which surrounded me at the Fairfield plantation?" 3 The alignment, in this instance, of her father's Jamaican plantation with the height of country and rural virtue is striking, to say the least. How is it possible that this novel can align plantation slavery, and by extension colonial wealth, with pastoral and rural purity? Indeed, the narrative's representation of Olivia's father is utterly antithetical in this respect to the popular image of the Jamaican planter in the late eighteenth century. As David Beck Ryden has observed, "West Indian planters, their families, and their descendants were regarded as conspicuously rich by anyone's standards in early modern Britain." "The wealth of Jamaican absentees," he continues,

was particularly noteworthy in the eighteenth century, as their political influence and connection to England's aristocracy made them minor celebrities...As a class, Jamaican absentee planters were renowned for living sumptuous lifestyles, renting or buying some of the most fashionable homes (in the West End of London) and large estates in the English, Welsh, or Scottish countryside. The Jamaican sugar planters sent their sons to the finest schools in England, relaxed in Bath, and took grand tours of Europe. ${ }^{4}$

started back with a momentary feeling nearly allied to disgust; for I beheld a skin approaching to the hue of a negro's, in the woman whom my father introduced to me as my intended wife!...A very few hours served to convince me, that whatever might have been the transient impression made by the colour of Olivia, her mind and form were cast in no common mould. She has a noble and dignified soul, which speaks in her words and actions; her person is raised above the standard of her sex, as much as her understanding and capacity...At one moment, I feel for her situation and pity her, - a stranger in a strange country, where she is more likely to receive contumely than consideration; at the next, I see in her a superior being; and again, I behold the child of humanity, the citizen of the world, with a heart teeming with benevolence and mercy towards every living creature!" (102-3).

3. Woman of Colour, 88.

4. David Beck Ryden, West Indian Slavery and British Abolition, 1783-1807 (Cambridge: Cambridge UP, 2009), 19. 
Olivia describes her father, by contrast, not as an absentee planter, but as conscientiously grounded in his estate, thoughtfully and capably tending to all and each. Unlike in the novel, the caricature of the Jamaican absentee planter in the popular British imagination turned precisely on his extreme negligence and neglect. As Ryden suggests, "The political power of the Jamaican planter reached its height during the late eighteenth century. Buoyed by the climbing sugar prices in the 179os, the island's political and economic elites left the colony for Britain in increasing numbers, where the prototypical absentee split his time between an exclusive London residence and a manor home in rural Britain."5 Olivia's father bears no resemblance whatsoever to those London-living, high-flying absentees who, as Ryden puts it, "lived up to the Jamaicans' reputation for excess." On the contrary, Mr. Fairfield stands as the absolute antithesis of those characters in the novel devoted to lives of fashion and dissipation. This essay will take up the seeming incoherence of the novel-the idea that plantation slavery is posited as the locus of rural virtue-in order to argue that the ideological contradiction at the novel's heart is, if not quite resolved, at least contained, in that the novel's antislavery politics is premised on a total refusal of economic logic as such.

\section{The Gentleman Planter and the Fall of the Planter Class}

There is a precedent, however, for this peculiar linkage of plantation slavery and rural virtue. In a discussion of Edward Long's 1774 History of Jamaica, Elizabeth Bohls observes that "Long's aesthetic vocabulary" constructs the "imperial countryside" as an "idyll in an attempt to make palatable the ugly foundation of West Indian fortunes." "Long's rhetorical persona is a true gentleman," Bohls argues; he is "a man of liberal education, wide-ranging knowledge, privileged leisure, and crucially, good taste." "Landownership," she continues, "anchored

5. Ryden, 41.

6. Ryden, 41 .

7. Elizabeth A. Bohls, “The gentleman planter and the metropole: Long's History of Jamaica (1774)," The Country and the City Revisited: England and the Politics of Culture, 1550-1850, eds. Gerald Maclean, Donna Landry, and Joseph P. Ward (Cambridge: Cambridge UP, 1999), 181. 
the gentleman's privileged status, and its display centered in the country house, that centrepiece of British culture."

Once Olivia arrives in England and dreams of a life with Augustus, she longs to set up home in the country, especially to get away from London and the fashionable and fickle world it represents. The fashionable life she finds tiresome is captured best by Augustus's brother and his wife, Mr. and Mrs. George Merton. Olivia comments that there exists in Mrs. Merton "such a splenetic tendency in every word she utters, such a look of design, accompanied with so much selfimportance, and so large a portion of conceit and affectation, with such frivolous conversation, that I seem hardly to consider her as a rational being." "As for Mr. George Merton himself, Olivia observes that "There is something, I think, not very far removed from ostentation in the manner of Mr. Merton." He "loves to talk of thousands and tens of thousands, in the indifferent careless way with which another would speak of pence." Perhaps because Mr. Merton's ostentation calls to mind the extravagance of Jamaican planters, Olivia notes that "Persons who have risen to importance by their own means, often fall into this failing. I have frequently remarked it among some of our wealthy planters."10 The Mertons are the first of several characters who stand for the superficial display associated with fashionable life in the city, and who make Olivia long for country life: "I am sick of the affectation and vanity of Mrs. Merton, and disgusted at her selfish and mercenary husband....My mind seems hampered, and I think I shall breathe more freely in the pure air, and amongst the sylvan scenes of the country."ll With a "fine Utopian scheme of domestic happiness in [her] head," Olivia declares that "the country must be the birth-place of it." All that she needs to be happy, apparently, is: "the conversation of my husband, a contemplation of the beauties of nature, and the society of rational and well-informed friends; books, music, drawing; the power of being useful to my fellow creatures."12

The doubling of the colonial plantation and the country estate can't help but make one think of Austen's Mansfield Park, and the

\footnotetext{
8. Bohls, 187 .

9. Woman of Colour, 73.

10. Woman of Colour, 75 .

11. Woman of Colour, 98.

12. Woman of Colour, 99.
} 
complex linkages between the mismanagement of Sir Thomas's Antigua estate and the unruliness and lack of government at Mansfield Park during his absence. The suggestion of Sir Thomas's declining fortune due to the declining profits from West Indian sugar plantations in the early years of the nineteenth century is in line with what Lowell Ragatz suggests in The Fall of the Planter Class in the British Caribbean, where he observes that several parliamentary committees were struck in 1807 and 1808 (the year The Woman of Colour was published), to study the economic "distress" of West Indian planters. ${ }^{13}$ The reasons for the losses on West Indian plantations in the early nineteenth century are complex and multifaceted and have to do with a combination of factors, some economic, some political, some social. As Christer Petley has recently suggested, "From the end of the 1780 s, the planters' already precarious public image rapidly declined as increasing numbers of metropolitan commentators highlighted the barbarities inherent in West Indian slave societies." He continues:

The era of the French Revolution further destabilized the planters' world, raising the specter of democratic challenges to the status quo and throwing the arena of Atlantic commerce into a state of unpredictable disarray. By 1807 , abolitionists had succeeded in outlawing the British transatlantic slave trade...Within a period of about 50 years, therefore, plantation owners and slaveholders in the British Caribbean had seen their slave system questioned, undermined, reformed, and then abolished..$^{14}$

Ultimately, "a powerful slaveholding group whose activities had been at the heart of the British imperial economy" was, within a few decades of the nineteenth century, "diminished and marginalized."15

13. Lowell Joseph Ragatz, The Fall of the Planter Class in the British Caribbean, 1763-1833 (New York: Octagon Books, 1971 [1928]), 309. For more recent discussions of the planter class in the British Caribbean, see, in addition to Ryden, Christer Petley, "Rethinking the fall of the planter class," Atlantic Studies 9.1 (March 2012): 1-17. See also Petley's Slaveholders in Jamaica: Colonial Society and Culture during the Era of Abolition (London: Pickering and Chatto, 2009); Philip Curtain, The Rise and Fall of the Plantation Complex: Essays in Atlantic History (Cambridge, Cambridge UP, 1990); Nicholas Draper, The Price of Emancipation: Slave-Ownership, Compensation, and British Society at the End of Slavery (Cambridge: Cambridge UP, 2010).

14. Christer Petley, "Rethinking the fall of the planter class," $3-4$.

15. Petley, 4. For a thoroughgoing reinterpretation of the abolitionist and antislavery movements in late eighteenth- century Britain, see Christopher Leslie Brown, Moral Capital: Foundations of British Abolitionism (Chapel Hill: U of North Carolina 
Against the backdrop of a declining planter class in Jamaica, The Woman of Colour recasts the compromised figure of the Jamaican planter by introducing a different colonial figure-that of the Eastern nabob-with which to align corruption, excess, and fashionable ostentation. This alignment is what makes it possible to understand the colonial wealth from the Jamaican plantation as seemingly more virtuous and associated, at various points, with the "old customs, and old notions" of a long-established, rural tradition and way of life. ${ }^{16}$ When Olivia and Augustus first move to the country, Olivia happily reports that "Mr. Fairfield has patience with me in all my wild strolls, and sees a beautiful view of the sea, a disjointed rock, or a lofty tree, with an enthusiasm which equals mine."17 Their shared aesthetic sensibility is underwritten by a moral sensibility that recognizes, in the manner of a conservative, benevolent paternalism, their obligations to others. Olivia is pleased, for instance, that her husband "is also interested and entertained with the simple and untutored urchins of the cottages" and she "daily perceive[s], with renewed delight, that our sentiments, our opinions, and our principles coalesce."18

Such a pastoral and domestic idyll does not last, however. Discovering that the fashionable life of the city has followed them to the country in the form of their neighbours the Ingots, Olivia applauds Augustus for his "wonderful facility in general conversation," which helps him to deal with, as she puts it, "the genteel vulgar," by which she means "those important shallow-pated beings, who have but one recommendation-money!"19 Once again, Olivia draws a stark line,

Press, 2006). Brown writes, "For too long, since Thomas Clarkson's time, the antislavery movement in Britain had been treated as a natural consequence of late eighteenth-century trends, as if, in this era, organizing against the slave trade was an obvious and logical thing to do. This book proceeds from a different set of assumptions. It proposes that, viewed historically, antislavery organizing was odd rather than inevitable, a peculiar institution rather than the inevitable outcome or moral and cultural progress...[I]n key respects the British antislavery movement was a historical accident, a contingent event that just as easily might never have occurred" (30). See also Thomas Bender, ed., The Antislavery Debate: Capitalism and Abolitionism as a Problem in Historical Interpretation (Berkeley: U of California Press, 1992) and Philip Gould, Barbaric Traffic: Commerce and Antislavery in the Eighteenth Century Atlantic World (Cambridge, MA: Harvard UP, 2003).

16. Woman of Colour, 110.

17. Woman of Colour, 106.

18. Woman of Colour, 106.

19. Woman of Colour, 107. 
firmly differentiating her father's virtue from the vices of those around him: "We saw enough of these in the West Indies, where riches are speedily amassed-and that disgraceful traffic, which hardens the heart, and deadens the feelings, while it fills the purse, was eagerly prosecuted by such characters!"20 Olivia laments the fact that she and Augustus "purposely left the crowded haunts of the city, to escape from all the ceremonials of fashion and the tax which the arbitrary customs of the world has imposed so heavily upon reason and common sense." She continues: "Yet they have followed us into retirement, and, unless we would really turn hermits, and entirely seclude ourselves from society, we must be content to pay the common levy." ${ }^{21}$ In a perhaps wry recognition of her own impossible nostalgia for a lost pastoral idyll, she observes that "to form a truly unvitiated and primeval neighbourhood of undisturbed truth, simplicity and innocence, we must revert to the golden age, and to the rapt reveries of enthusiastic poets."22 In Olivia's conception of the city, there is no place for the enlightening, sociable, or liberal effects of commerce, the kind of view of commerce that is often associated, for instance, with the abolitionist and antislavery movements. Olivia's thoroughgoing "country" view sits, therefore, in a somewhat perplexing relation to her equally thoroughgoing antislavery sentiment.

Indeed, her country view fits closely, at certain moments, with the conservative paternalism of the trope of the "grateful slave." Discussing this popular eighteenth-century literary figure, George Boulukos has suggested that it "describes the successful reform of slave plantations through the ameliorative efforts of a sentimental planter or overseer; the reforms end brutal punishment of slaves, and the slaves become personally devoted to the reformer in gratitude for his kindness."23

20. Woman of Colour, 107.

21. Woman of Colour, 125 .

22. Woman of Colour, 125 .

23. George Boulukos, The Grateful Slave: The Emergence of Race in EighteenthCentury British and American Culture (Cambridge: Cambridge UP, 2008), 2-3. Boulukos argues that scholars have neglected to notice that the trope of the grateful slave "depends for its success on two key assumptions: first, that plantation slavery will continue in a brutal form that makes the humane reformers' efforts remarkable, and second, that Africans can be induced not just to accept slavery, but to embrace it, to be overwhelmed by ecstatic gratitude toward someone who continues to claim mastery over them" (3). 
Mr. Fairfield, Olivia's father, is drawn entirely in the mould of the sentimental planter who attempts to "reform abuses" on his plantation, but because "his health was daily declining," was not in a position to "adopt a line of conduct which would draw on him the odium of all his countrymen." 24 From his position of passivity, "he contented himself, therefore, with seeing that slaves on his estate were well kept and fed, and treated with humanity." The only moment in the narrative in which Olivia offers even the slightest criticism of her father comes with her observation that the slaves' "minds were suffered to remain in the dormant state in which he found them!"25 As Lyndon Dominique notes, Olivia's comment constitutes "an ideological stab at the policy of benevolent paternalism famously espoused in Edgeworth's 'The Grateful Negro.' Neither Mr. Edwards nor Mr. Fairfield tries to improve their slaves intellectually. By pointing this out, Olivia is directly critiquing the extent of her father's benevolence." ${ }^{26}$

\section{Fashionable Animals}

The novel quite clearly displaces the issue of slavery per se by a trenchant critique of commerce, and uses that critique to bolster its antislavery argument. Embodied largely by the array of "nabobs" and other fashionable, new-moneyed characters recently returned from the "East," commerce is itself understood in the novel as a form of slavery, and its adherents are the languishing, sensual, thoroughly Orientalized figures so familiar from texts in this period. Describing the "Pagoda," "the newly-raised edifice" of the aptly-named "Sir Marmaduke Ingot," Olivia observes that "every order of architecture has been blended in this structure.” As for the Ingots themselves,

The eastern nabob seemed to have harnessed his fleetest Arabian coursers to his chariot, when he came to pay his compliments to us; he really cut an appearance quite magnifique, as his gay equipage and dashy attendants drove through the park; - we knew there could be only one family so dazzling in this neighbourhood, and were therefore prepared for the guests, who made their entrée. ${ }^{27}$

24. Woman of Colour, 55 .

25. Woman of Colour, 55 .

26. Lyndon Dominique, The Woman of Colour, 55, note 1.

27. Woman of Colour, 108. 
We learn that Sir Marmaduke "acquired a very considerable fortune at Bengal" and likes "to keep a hospitable and showy table, and to have his house filled with company" and that "the good dinners, the turtle, and the curries at the Pagoda, obtain for her ladyship general sufferance, if not general favour. It was a very sultry morning, but Lady Ingot was wrapped in a most superb oriental shawl, while a fine lace veil descended almost to the ground, in some measure softening the asperity of her features by its partial shade." ${ }^{28}$ Even the Ingots' son is described as "wrapped in a shawl, and his delicate fingers were warmed in a muff of the finest ermine, almost as large as himself (for he is very effeminate and diminutive in person). His head was adorned by a hat, turned up before, with a gold button and loop, and ornamented by a plume of feathers; he is really a pretty looking stripling, if he was not made so mere a monkey of." ${ }^{29}$ Characters aligned with new money such as the Ingots are in thrall to fashion and its tyrannical regime, as opposed to those, like Olivia, aligned with "old" money and good taste.

Characters in the novel associated with fashion are also frequently depicted by Olivia as belonging to "a different species" in the manner of the Ingots' son. The entire Ingot family, for instance, "are a new species of animal." ${ }^{30}$ And when Olivia attends a ball early in the novel, she observes a woman who has ostrich feathers "mounted in several directions from her head, while her bared ears, and elbows, and back, and bosom, gave to her whole contour, so freezing and so forlorn an appearance, while her volatility, and frisky and girlish airs, made her a person so very conspicuous," that Olivia "could not help surveying her with the utmost curiosity, as a species of animal which had never before fallen under [her] notice." 31 Firmly aligning new money, ostentation, and bad taste with a "new species of animal," the novel carefully and strategically relocates questions about species distinction and the limits of the human from the category of race to that of commerce, fashion, and commodification.

Thus while commerce is without question the explicit object of the novel's critique, its presence is also crucial to bolstering the view that Olivia, the "woman of colour," is practically the only character in the

28. Woman of Colour, 108.

29. Woman of Colour, 108.

30. Woman of Colour, 122.

31. Woman of Colour, 87. 
entire novel who truly embodies virtuous reason. It is after her encounter with various "species of animal" at the ball, that Olivia writes to her friend that she is "disappointed in England" because she "expected to meet with sensible, liberal, well informed and rational people" but "has not found them." 32 One of the only characters who embodies both virtue and reason in equal measure is also the one who, because of her skin colour, is most frequently perceived by others as having neither. Upon meeting Mrs. George Merton for the first time, Olivia observes that she hardly seems a "rational being," but goes on to note, wryly, "that she considers me as but one remove from the brute creation, is very evident." 33 The novel is at pains to demonstrate that the characters who consider Olivia but one remove from the brute creation are themselves brutes without reason. In the opening letter of the novel Olivia writes: "We are considered, my dear Mrs. Milbanke, as an inferior race, but little removed from the brutes, because the Almighty Maker of all-created beings has tinged our skins with jet instead of ivory!" 34 The narrative repeatedly makes clear that the "inferior race" is marked not by its skin colour, but by its enslavement to fashion and commerce. Thus the novel's didacticism is not in service of convincing readers that a "woman of colour" has the capacity for reason, so much as showing beyond a doubt that she is one of the few, of any skin colour, with the capacity for reason whatsoever. In this respect, the novel's 1808 publication date makes it a strikingly late example of what Dror Wahrman has referred to as the "ancien régime of identity," or what Roxann Wheeler sees as the greater fluidity or changeableness of racial identity in the eighteenth century, as opposed to the biological racism of the nineteenth century. ${ }^{35}$

Lest readers are unable to recognise the novel's displacement of the locus of brute creation from race to commerce, the narrative offers up a highly sentimental scene in order to underscore the move. As Olivia realizes that her dream of a quiet life of country contentment is not to be because of Augustus' prior commitment to the orphaned

32. Woman of Colour, 88.

33. Woman of Colour, 73 .

34. Woman of Colour, 53 .

35. See Dror Wahrman, The Making of the Modern Self (New Haven: Yale UP, 2004) xiii, and Roxann Wheeler, The Complexion of Race: Categories of Difference in Eighteenth-Century British Culture (Philadelphia: U of Pennsylvania Press, 2000). 
Angelina Forrester, Olivia is utterly in despair. Seeing her struggle, her friend Mr. Lumley uses the occasion to exclaim, "Oh, come here, ye prejudiced, narrow-minded beings! Oh come hither, ye advocates for slavery!"

Ye who talk of the inferiority of reason, which attends a difference of colour, - oh, come here! And see a woman,-a young - a tender woman, who, in the contemplation of her own unparalleled misfortunes, and with a heart almost broken by affliction, yet rises with unexampled preeminence of virtue! See here a conquest over self, which ye would vainly try to imitate! ${ }^{36}$

Given the novel's consistent focus on the "inferiority of reason" which attaches to all of the fashionable and ostentatious characters whom Olivia encounters, this scene of instruction seems excessive, even unnecessary. The scene is uncomfortable, furthermore, because it constitutes an extravagant objectification of Olivia's suffering. Violently turning the reader's focus away from Olivia's interior first-person narration and toward, instead, an almost pornographic image of her suffering, this scene strives to depict Olivia's virtuous sensibility in the face of great sorrow, but in the event traffics in the most hackneyed and hoary clichés of the sentimental novel. For a novel whose ostensible purpose is a strong critique of commerce, this scene veers dangerously close to commodifying its heroine. ${ }^{37}$

The Woman of Colour might seem to be ideologically incoherent. Indeed, what are we to make of a novel that defends rural virtue, and by extension a seeming parochialism, against the worldliness and corruption of the city and commerce, while at the same time quietly

36. Woman of Colour, 148.

37. See Marcus Wood, Slavery, Empathy and Pornography (Oxford: Oxford UP, 2002). The scene above conjures Olivia's mother, whom we meet only briefly at the start of the novel. Marcia is a slave who is seduced by Olivia's father, her owner. She converts to Christianity only to realize that her seducer has acted entirely against the dictates of his religion: "He made her start with horror at the crime of which she had been innocently guilty: and the new Christian pointed her finger at him, who, educated under the influence of the Gospel, lived in direct opposition to its laws!" (54). Olivia's father's defense is rather weak, especially given the esteem in which he is held by his beloved daughter: "He loved Marcia with fervour; but the pride of the man, the quick feeling of the European, the prejudices which he had imbibed in common with his countrymen, forbade his making this affectionate and heroic girl his wife" (55). 
promoting an urbane, liberal, anti-slavery sentiment? I wonder, however, whether what seems like incoherence really is not. The most strictly anti-economic language available to Olivia is classic "country" rhetoric. The antislavery politics of this novel are premised on an absolute rejection of commerce-or "traffic" in any form whatsoever. Christopher Leslie Brown argues that what has been called the "humanitarian thesis" - the idea that British abolitionism was prompted by a shift in morality-has long been a mainstay of the histories of abolitionism and antislavery. He suggests, however, that the humanitarian thesis aligned with abolitionists has in some quarters long been considered an alibi of sorts for what were more nakedly economic, political, and imperial interests. As Brown observes, "Antislavery thought in the eighteenth century did not build cumulatively, block by block, to a higher stage of moral consciousness."

The essentials of the case against the enslavement of Africans had been articulated long before the antislavery movements began. Nor did the intensity of antislavery sentiment swell to a breaking point in the late eighteenth century from which it loosed abolitionist fervour across the cultural landscape. Politics...more than public opinion, placed slave trade abolition on the public agenda. ${ }^{38}$

If abolitionists themselves used economic language and arguments to justify their antislavery positions - the idea that ending slavery would be in the end more profitable was a common one-then it follows that a complete rejection of commerce was the basis for the most thoroughgoing antislavery logic at the time.

Olivia ends in the novel as she began, in her beloved Jamaica, where she will "zealously" engage herself, as she says, "in instructing the minds-in mending the morals of our poor blacks." ${ }^{39}$ The novel concludes with a conversation between the editor of the manuscript and a friend, who chastises the editor for not rewarding Olivia with "the usual meed of virtue-a husband!" Alas, virtue, claims the editor, "may truly be said to be its own reward" and "if these pages should teach...one sceptical European to look with a compassionate eye towards the despised native of Africa, then, whether Olivia Fairfield be a real or imaginary character, I shall not regret that I have edited the

38. Brown, 40.

39. Woman of Colour, 188. 
Letters of a Woman of Colour!" 40 This final note falling, as it does, on the "despised native of Africa," suggests the extent to which the novel's sustained critique of commerce is ultimately in service of its antislavery politics, a politics predicated on an absolute rejection of commerce and its dehumanizing and deracinating tendencies.

40. Woman of Colour, 189 . 